\title{
Floristic composition and stand structure of mangrove forests with varying vegetation conditions in Sungai Apit, Siak, Riau, Indonesia
}

\author{
SITI FATONAH ${ }^{1, \vartheta}$, RASOEL HAMIDY $^{2, v v}$, ARAS MULYADI $^{3}$, EFRIYELDI $^{4, v v v}$ \\ ${ }^{1}$ Department of Biology, Faculty of Mathematics and Natural Sciences, Universitas Riau. Kampus Bina Widya, Jl. H.R. Subrantas Km 12,5, Panam, \\ Pekanbaru 28293, Riau, Indonesia. Tel./fax.: +62-761-62232. ^email: fath0104@gmail.com \\ ${ }^{2}$ Department of Environmental Science, Graduate Program, Universitas Riau. Kampus Bina Widya, Jl. H.R. Subrantas Km 12,5, Panam, Pekanbaru \\ 28293, Riau, Indonesia. •"email: rasoel_hamidy@yahoo.com \\ ${ }^{3}$ Department of Marine Science, Faculty of Fisheries and Marine Science, Universitas Riau. Kampus Bina Widya, Jl. H.R. Subrantas Km 12,5, Panam, \\ Pekanbaru 28293, Riau, Indonesia."vvemail: efriyeldiedi@gmail.com
}

Manuscript received: 14 April 2021. Revision accepted: 28 August 2021

\begin{abstract}
Fatonah S, Hamidy R, Mulyadi A, Efriyeldi. 2021. Floristic composition and stand structure of mangrove forests with varying vegetation conditions in Sungai Apit, Siak, Riau, Indonesia. Biodiversitas 22: 3972-3983. Mangrove forest in Sungai Apit Sub-district, Siak District, Riau is one of mangrove ecosystems that is still partly natural with some parts being damaged or rehabilitated. Degraded mangrove forest is a mangrove forest that has been disturbed by human activities and natural factors. This study aimed to investigate the floristic composition and stand structure of trees and seedlings in mangrove forests in Sungai Apit, Siak District, Riau Province, Indonesia in three vegetation conditions, i.e., natural, degraded, and rehabilitated forests. Line Transect Plot Method was used to collect data in three stations (i.e., Rawa Mekar Jaya, Sungai Rawa and Mengkapan villages) where each station consisted of three transects with a size of $10 \times 100 \mathrm{~m}$. A total of 20 species belonging 11 families were recorded in the studied sites with Rhizophora apiculata was the most dominant species in all forest conditions. The natural forest had the highest number of species followed by rehabilitated forest and the degraded forest. Stand structure in terms of tree density, mean diameter of mangrove trunks, and basal area differed significantly across the three vegetation conditions with the natural forest had the highest values followed by the rehabilitated forest, while the degraded forest was the lowest. For the seedling, the lowest number of species was observed in the degraded forest while the highest was in the rehabilitated forest, indicating the result of rehabilitation activities. Yet, seedling density in natural forests was lower than that in rehabilitated and degraded forests. This study provides information that differences in structure, species composition and recruitment of seedlings in mangrove forests in the three conditions and locations can be related to differences in recovery time and degradation levels which may be important for developing mangrove forest management and conservation strategies.
\end{abstract}

Keywords: Floristic composition, mangrove forest condition, seedling density, stand structure, Sungai Apit, Siak

\section{INTRODUCTION}

Mangrove forests are complex and productive ecosystems that are very important for humans because they provide ecological and economic functions. This is because mangrove forests provide a variety of ecosystem services, including provisioning (food, fuel, medicines, and honey), regulatory (storm protection, erosion control, and climate regulation), cultural (spiritual, recreational and aesthetic), and supporting (habitat function) (Vo et al. 2012).

More than two-thirds of mangrove forests occur in only 12 countries with Indonesia accounting for more than $20 \%$ of the global mangrove area. About 3 million hectares of mangrove forest grow along Indonesia's 95,000 km coastline. Mangrove forests are found in various parts of Indonesia, with important regional mangrove ecosystems located in Papua, Kalimantan and Sumatra (FAO 2007; Giri et al. 2011).

Over the past three decades, Indonesia has lost 40 percent of its mangrove forests, which represents the fastest rate of mangrove destruction in the world. Mangrove ecosystems have been under increasing pressure due to over exploitation, pollution, and deforestation. Mangrove degradation is mostly caused by anthropogenic activities, such as forest clearing for ponds and aquaculture, oil palm plantation and as well as illegal logging due to the increasing demand for wood production (Brander et al. 2012; Campbell and Brown 2015; Owuor et al. 2019). Degraded mangrove forests generally show a low-density level and are dominated by juvenile stages or young vegetation (Onrizal 2008).

Vegetation analysis in mangrove forests is a tool to assess the condition of vegetation whether it is in intact or in degraded condition. Vegetation analysis is also important to investigate the dynamics of the vegetation following forest rehabilitation. Assessments of species composition, dominant species and pattern of seedling colonization are important in the protection and conservation of mangrove ecosystems. Also, regeneration is essential for the preservation of the mangrove ecosystem. Moreover, the understanding of vegetational structure and regeneration patterns of mangroves are important in developing management strategies (Alemayehu and Wekesa 2017). The ability of mangrove species to regenerate is related to reproductive capacity, growth, 
survival and competition of vegetation at young stages. This aspect is important since the viability of young mangrove plants in canopy gaps is generally greater than those growing in full shade (Azad et al. 2020).

The floristic composition and structure of tree and seedlings in various mangrove forests had been studied with observations showing different compositional and stand structures (Sawale and Thivakaranet 2013; Shah et al. 2016; Dharmawan and Widyastuti 2017; Alemayehu and Wekesa 2017; Kantharajan et al. 2018; Pototan et al. 2021; Azad et al. 2020; Rasquinha and Mishra 2020; Pototan et al. 2021; Sreelekshmi et al. 2020; Njana 2020).

Riau Province is one of the provinces in Indonesia that has been experiencing deforestation and degradation of its mangrove forests. Mangrove destruction in this province was intensifying in the 1990s and still continues these days. Currently, Riau has about 261,285 ha of mangrove forests on the shoreline or coastal areas with the indication of this ecosystem appearing to decrease. In 2008, there were only 4,850 hectares of mangrove forest in the province that remained intact with only a few meters width to the land (Yurizal 2018). A study on the structure of mangrove vegetation in Riau Province had been carried out by Mulyadi and Amin (2016).

Mangrove forest in Sungai Apit Sub-district, Siak District, Riau Province, Indonesia is one of mangrove ecosystems that is still partly natural with some parts being damaged or rehabilitated. The differences in mangrove land conditions in Siak District, which includes natural, degraded, and rehabilitated forests resulted in differences in the structure and floristic composition of trees and seedlings. The natural mangrove forest in Sungai Apit is a secondary forest that has not been disturbed for years. Degraded mangrove forest is a mangrove forest that has been disturbed by human activities and natural factors. The main cause of mangrove forest degradation and a decrease in mangrove area in Sungai Apit was the massive felling of mangrove trees around 2000, mainly due to the demand for piles for buildings. Currently, there are still threats to mangrove areas especially the activity of taking wood for charcoal raw materials, deforestation of mangrove land for conversion to oil palm plantations and abrasion and waves crashing. Rehabilitated forest is a mangrove forest that was previously degraded with severe level of disturbance and mangrove seedlings have been planted. Rehabilitation of mangrove forests is carried out on mangrove areas with more severe disturbance levels. Mangrove rehabilitation efforts have been carried out by the people of Sungai Apit starting in 2002.

Efriyeldi et al. (2020) assessed the condition of mangrove vegetation in Sungai Apit, Siak, Riau, at three stations (Lalang, Bunsur, and Sungai Rawa) in which mangrove species with high density at the three stations were Avicennia alba, Sonneratia alba, and Rhizophora apiculata. The mangrove ecosystem in that location was assessed based on tree density from rare to dense.
However, this method has limitation when the assessment combined trees and saplings simultaneously, resulting in the condition of the mangroves being classified as good since they had very dense stands. This study aimed to investigate the floristic composition and stand structure of trees and seedlings in mangrove forests in Sungai Apit in three mangrove forest conditions, i.e., natural, degraded, and rehabilitated forests.

\section{MATERIALS AND METHODS}

\section{Study site and period}

The research was conducted in Sungai Apit Subdistrict, Siak District, Riau Province, Indonesia (Figure 1). Three villages, namely Rawa Mekar Jaya, Sungai Rawa and Mengkapan were selected as sampling locations as excellent context to represent varying conditions of mangrove forest. The sampling station was determined based on the conditions of the mangrove ecosystem, namely natural, rehabilitated, and degraded forests that have not been rehabilitated. Several coordinate points were taken to represent the three conditions in the three villages.

Degraded forest was a disturbed forest that was not rehabilitated. The degraded forest in Rawa Mekar Jaya was a forest that had been damaged by logging and was currently being disturbed due to the construction of canals and its proximity to the clearing of mangrove forests (deforestation) for oil palm plantations. The degraded forest in the Sungai Rawa occurred because it is close to ports and settlements and former charcoal production. Ongoing disturbances in disturbed forests in Sungai Rawa and Mengkapan occur due to abrasion resulting in inundation and strong sea waves crashing.

In 2014, rehabilitation through planting of mangrove started in Rawa Mekar Jaya, and had been routinely carried out every year, until 2019. Mangrove rehabilitation in Sungai Rawa was carried out from 2008 to 2018, while it was conducted from 2002 to 2016 in Mengkapan. The sampling point for rehabilitated forest in Rawa Mekar Jaya was a rehabilitation forest with an age of about four years. The age of the rehabilitated forest in Sungai Rawa observed was about five years, while in Mengapan it was about 7 years. Mangrove rehabilitation activities were carried out by non-governmental organizations with assistance from government agencies and the private sector. Activities conducted by the community, among others, include the Tourism Awareness, Mangrove Observer and Nursery Groups. Species planted included $R$. apiculata, Rhizophora mucronata, A. alba, Avicennia marina, Bruguiera sexangula, Bruguiera hainesii and Bruguiera gymnorrhiza. The spacing for Rhizophora was about $1 \times 1 \mathrm{~m}$, while for other genera it was about $2 \times 2 \mathrm{~m}$. The percentage of growing seedlings was about 40 to $80 \%$. 

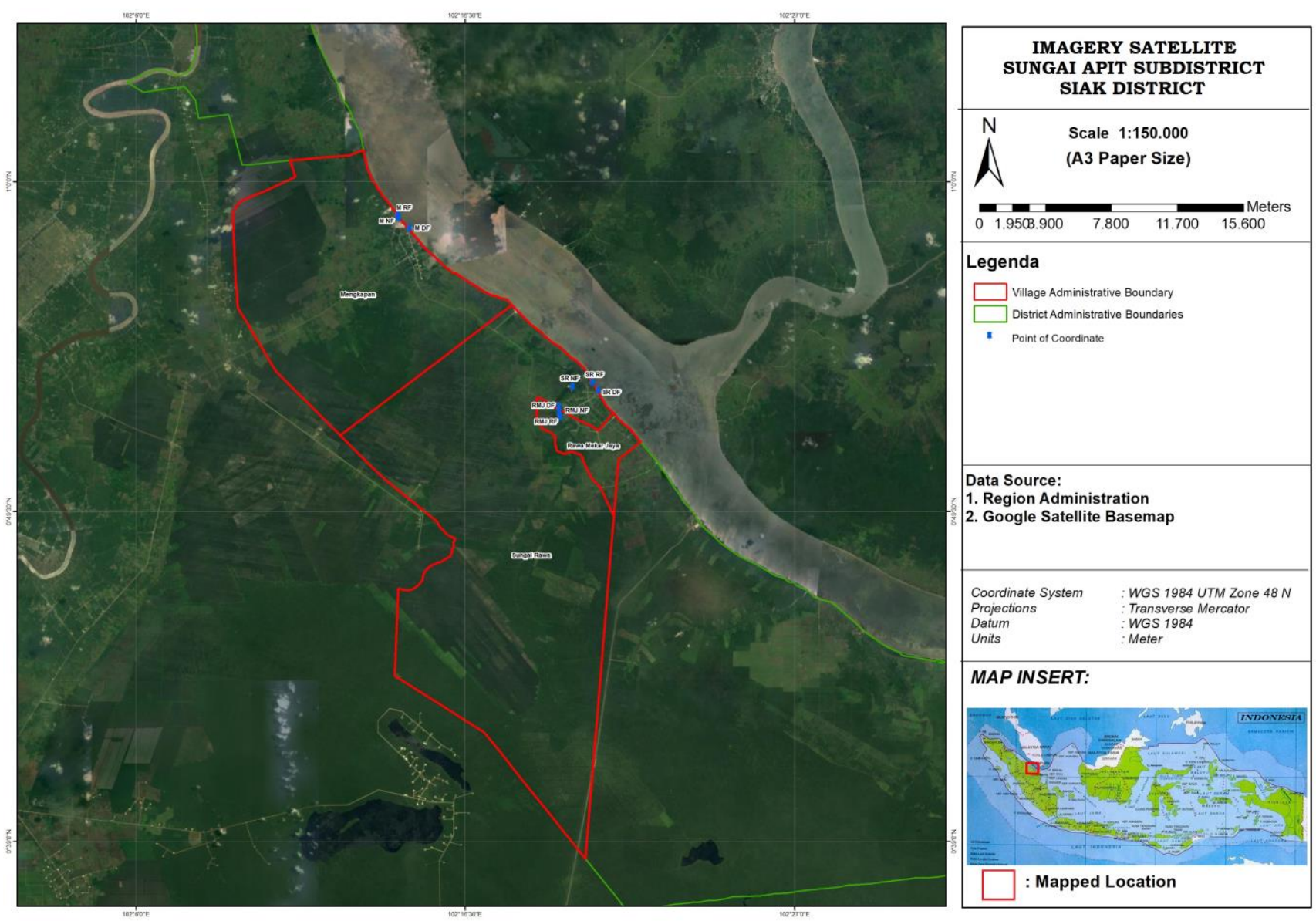

Figure 1. Map of the study sites in Sungai Apit, Siak District, Riau Province, Indonesia. Notes: NF: natural forest; RF: rehabilitated forest; DF: degraded forest

\section{Data collection}

Data was collected using the Line Transect Plot Method. In each village, three stations representing the condition of mangrove forests (natural, rehabilitated, and degraded forests) were established. At each sample location studied, three transect lines were created with a width and length of 10 and $100 \mathrm{~m}$, respectively, or equivalent to 1000 $\mathrm{m}^{2}$ of sampling area per transect. Three plots of $10 \mathrm{~m} \times 10$ $\mathrm{m}$ for trees and $2 \mathrm{~m} \times 2 \mathrm{~m}$ for seedlings were made on each transect line. The species that occurred at each plot were identified using resources published by Wetlands International Indonesia Program (http://www.wetlands.or.id/mangrove/mangrove_species.p $\mathrm{hp}$ ?id=11). All trees and seedlings encountered at each plot were counted with individual trees being measured around the trunk in order to determine the diameter at breast height (at $1.3 \mathrm{~m}$ ). In addition, the actual and total numbers of individual seedling species per plot were further recorded (Mauludin et al. 2018).

\section{Data analysis}

Vegetation analysis data (number of individual trees and seedlings, and tree diameter at breast height (DBH)) were analyzed using Microsoft Excel in order to obtain important values describing stand characteristics, such as the total number of species, tree density (individuals per ha), mean diameter $(\mathrm{DBH})$, basal area $\left(\mathrm{m}^{2} / \mathrm{ha}\right)$, ShannonWiener index of diversity (H '), Pielou's index of evenness (j), and Species index of dominance (c). Also, the Importance Value Index IV (\%) of species was calculated to determine the dominant tree and seedling species based on relative density, frequency, and coverage (basal area). The Shannon and Pielou (Pielou 1969) indices were also used to calculate species diversity and evenness/equality, respectively (Budiharta 2010; Alemayehu and Wekesa 2017; Rasquinha and Mishra 2020; Azad et al. 2020; Pototan et al. 2021). Natural regeneration patterns were further determined based on seedling density and the number of species with composition and dominance. These data were analyzed descriptively in the form of percentage value to seek the decline or increase of the condition in the rehabilitated versus in the degraded forests, after being compared with the stand characteristic values of natural mangrove ecosystems (Azad et al. 2020). 


\section{RESULTS AND DISCUSSION}

\section{Tree species composition and dominance}

The species composition and dominance of trees in varying conditions of mangrove forests in three villages (Rawa Mekar Jaya, Sungai Rawa, and Mengkapan) at Sungai Apit Subdistrict, Siak District, Riau Province, Indonesia are shown in Tables 1, 2, and 3.

In total, 20 tree species from 11 families were discovered in these nine sampling locations, namely $R$. apiculata, Rhizophora stylosa, R. mucronata, Xylocarpus granatum, Xylocarpus moluccensis, Sonneratia caseolaris, Sonneratia ovata, S. alba, B. gymnorrhiza, B. sexangula, B. hainesii, and Scyphiphora hydrophyllacea. There were also non-mangrove plants including rukam (Flacourtia rukam), Waru (Hibiscus tilliaceus), gurah (Cledodendron serratum), and bedaru (Urandra corniculata). The three villages showed different numbers of species with the highest value was discovered in Sungai Rawa (16), followed by Mengkapan (13) and the lowest was at Rawa Mekar Jaya (7). The differences in species composition occurred in the three conditions of mangrove forests at the selected villages in Sungai Apit, Siak. Natural mangrove forests showed the highest number of species in Rawa Mekar Jaya, Sungai Rawa, and Mengkapan with 5, 11, and 11 , followed by rehabilitated mangrove with 5,8 , and 7 , and degraded mangrove with 3,4 , and 6 , respectively.

The natural and rehabilitated forests were generally dominated by Rhizophora apiculata, except the rehabilitated forest in Mengkapan which was dominated by $A$. alba with the second-order being $R$. apiculata. The dominant mangrove species in the degraded forests were $R$. apiculata in Rawa Mekar Jaya, and S. alba in Sungai Rawa and Mengkapan. R. apiculata also dominated mangrove forest in other regions, for example, Dumai Coastal Area, Riau (Mulyadi and Amin 2016), Sibuti mangrove forest,
Sarawak, Malaysia (Shah et al. 2016), and Teluk Adang Nature Reserve (TANR) East Kalimantan, Indonesia (Mukhlisi et al. 2020).

There was a difference in species composition between the natural, rehabilitated, and degraded forests. There was a decline in the number of species that occurred in the degraded forests as well as in tree species composition. Forest disturbance and vegetational rehabilitation were also observed to have resulted in a decrease and increase in the number of species. $R$. apiculata was a species that dominated natural forest in Rawa Mekar Jaya, Sungai Rawa and Mengkapan, as it also grew in the rehabilitated and degraded mangrove zones. Another mangrove species that grew in all forest conditions was A. alba.

There were differences in the total number of mangrove species in the natural, rehabilitated, and degraded forests. The natural mangrove forest in Rawa Mekar Jaya showed the lowest number of species (5) compared to Sungai Rawa and Mengkapan (12). There was an increase in the number of species up to $20 \%$ (6 species) in the rehabilitated forest in Rawa Mekar Jaya, while the values in the degraded mangrove remained stagnant (neither decreased or increased). The changes in mangrove forests from natural conditions resulted in a decrease in the number of species at Sungai Rawa and Mengkapan, with the decline higher at both locations in the degraded forest, reaching $66.67 \%$ and $50 \%$, respectively. These results indicate that the rehabilitation activities by local communities are successful in increasing species diversity.

\section{Structure and diversity of tree stands}

The structure and diversity of mangrove tree stand in Sungai Apit in varying mangrove forest conditions are presented in Table 4.

Table 1. Species composition and dominance of tree in Rawa Mekar Jaya, Sungai Apit, Siak, Riau, Indonesia

\begin{tabular}{|c|c|c|c|c|c|c|}
\hline $\begin{array}{c}\text { Forest } \\
\text { condition }\end{array}$ & Species & Family & $\begin{array}{c}\text { Relative } \\
\text { density } \\
(\%)\end{array}$ & $\begin{array}{c}\text { Relative } \\
\text { frequency } \\
(\%)\end{array}$ & $\begin{array}{c}\begin{array}{c}\text { Relative } \\
\text { dominance } \\
(\%)\end{array} \\
\end{array}$ & $\begin{array}{c}\text { Importance } \\
\text { value }(\%)\end{array}$ \\
\hline \multirow[t]{5}{*}{ Natural forest } & Rhizophora apiculata $\mathrm{Bl}$. & Rhizophoraceae & 81.01 & 42.86 & 86.20 & 210.07 \\
\hline & Bruguiera sexangula (Lour.) Poir. & Rhizophoraceae & 6.96 & 28.57 & 2.89 & 38.42 \\
\hline & Rhizophora mucronata Lam. & Rhizophoraceae & 8.86 & 19.05 & 9.64 & 37.55 \\
\hline & Heritiera littoralis Korth. & Sterculiaceae & 1.90 & 4.76 & 0.34 & 7.00 \\
\hline & Clerodendrum serratum (L.) Spr. AP & Lamiaceae & 1.27 & 4.76 & 0.94 & 6.96 \\
\hline \multirow{5}{*}{$\begin{array}{l}\text { Rehabilitated } \\
\text { forest }\end{array}$} & Rhizophora apiculata $\mathrm{Bl}$. & Rhizophoraceae & 71.35 & 71.35 & 71.35 & 176.91 \\
\hline & Bruguiera sexangula (Lour.) Poir. & Rhizophoraceae & 17.44 & 17.44 & 17.44 & 70.75 \\
\hline & Urandra corniculate (Becc.) Foxw. & Icacinaceae & 7.06 & 7.06 & 7.06 & 31.69 \\
\hline & Sonneratia alba J.E. Smith & Lythraceae & 3.35 & 3.35 & 3.35 & 13.41 \\
\hline & Rhizophora mucronata Lam. & Rhizophoraceae & 0.80 & 0.80 & 0.80 & 7.25 \\
\hline \multirow[t]{3}{*}{ Degraded forest } & Rhizophora apiculata $\mathrm{Bl}$. & Rhizophoraceae & 70.40 & 70.40 & 70.40 & 192.79 \\
\hline & Rhizophora mucronata Lam. & Rhizophoraceae & 27.69 & 27.69 & 27.69 & 88.94 \\
\hline & Bruguiera sexangula (Lour.) Poir. & Rhizophoraceae & 1.91 & 1.91 & 1.91 & 18.27 \\
\hline
\end{tabular}


Table 2. Species composition and dominance of tree in Sungai Rawa, Sungai Apit, Siak, Riau, Indonesia

\begin{tabular}{|c|c|c|c|c|c|c|}
\hline Forest condition & Species & Family & $\begin{array}{c}\text { Relative } \\
\text { density } \\
(\%)\end{array}$ & $\begin{array}{c}\text { Relative } \\
\text { frequency } \\
(\%)\end{array}$ & $\begin{array}{c}\text { Relative } \\
\text { dominance } \\
(\%)\end{array}$ & $\begin{array}{c}\text { Importance } \\
\text { value }(\%)\end{array}$ \\
\hline \multirow[t]{11}{*}{ Natural forest } & Rhizophora apiculata Bl. & Rhizophoraceae & 64.92 & 64.92 & 64.92 & 153.51 \\
\hline & Xylocarpus granatum Koen. & Meliaceae & 13.47 & 13.47 & 13.47 & 44.06 \\
\hline & Rhizophora mucronata Lam. & Rhizophoraceae & 3.15 & 3.15 & 3.15 & 24.77 \\
\hline & Xylocarpus moluccensis (Lam) M.Roem. & Meliaceae & 4.49 & 4.49 & 4.49 & 19.72 \\
\hline & Sonneratia caseolaris (L.) Engl. & Lythraceae & 6.24 & 6.24 & 6.24 & 10.91 \\
\hline & Bruguiera gymnorrhiza (L.) Lamk. & Rhizophoraceae & 2.54 & 2.54 & 2.54 & 10.91 \\
\hline & Rhizophora stylosa Griff. & Rhizophoraceae & 0.98 & 0.98 & 0.98 & 9.66 \\
\hline & Flacourtia rukam Zoll. \& Mor. & Salicaceae & 0.72 & 0.72 & 0.72 & 9.66 \\
\hline & Bruguiera sexangula (Lour.) Poir. & Rhizophoraceae & 1.44 & 1.44 & 1.44 & 8.40 \\
\hline & Sonneratia alba J.E. Smith & Lythraceae & 1.51 & 1.51 & 1.51 & 4.20 \\
\hline & Bruguiera hainesii C.G.Rogers & Rhizophoraceae & 0.53 & 0.53 & 0.53 & 4.20 \\
\hline \multirow{8}{*}{$\begin{array}{l}\text { Rehabilitated } \\
\text { forest }\end{array}$} & Rhizophora apiculata B1. & Rhizophoraceae & 53.63 & 53.63 & 53.63 & 130.21 \\
\hline & Xylocarpus granatum Koen. & Meliaceae & 22.81 & 22.81 & 22.81 & 58.59 \\
\hline & Bruguiera hainesii C.G.Rogers & Rhizophoraceae & 1.85 & 1.85 & 1.85 & 29.21 \\
\hline & Scyphiphora hydrophyllacea C.F.Gaertn. & Rubiaceae & 9.38 & 9.38 & 9.38 & 27.05 \\
\hline & Bruguiera sexangula (Lour.) Poir. & Rhizophoraceae & 3.70 & 3.70 & 3.70 & 22.12 \\
\hline & Ceriops tagal C.B. Rob. & Rhizophoraceae & 3.81 & 3.81 & 3.81 & 13.66 \\
\hline & Bruguiera gymnorrhiza (L.) Lamk. & Rhizophoraceae & 2.56 & 2.56 & 2.56 & 11.58 \\
\hline & Sonneratia alba J.E. Smith & Lythraceae & 2.24 & 2.24 & 2.24 & 7.58 \\
\hline \multirow[t]{4}{*}{ Degraded forest } & Sonneratia alba J.E. Smith & Lythraceae & 45.01 & 45.01 & 45.01 & 120.51 \\
\hline & Avicennia alba $\mathrm{Bl}$. & Acanthaceae & 37.38 & 37.38 & 37.38 & 110.62 \\
\hline & Sonneratia ovata Back. & Lythraceae & 14.59 & 14.59 & 14.59 & 46.89 \\
\hline & Avicennia marina (Forssk.) Vierh & Acanthaceae & 3.02 & 3.02 & 3.02 & 21.98 \\
\hline
\end{tabular}

Table 3. Species composition and dominance of tree in Mengkapan, Sungai Apit, Siak, Riau, Indonesia

\begin{tabular}{|c|c|c|c|c|c|c|}
\hline Forest condition & Species & Family & $\begin{array}{c}\text { Relative } \\
\text { density } \\
(\%)\end{array}$ & $\begin{array}{c}\text { Relative } \\
\text { frequency } \\
(\%)\end{array}$ & $\begin{array}{c}\text { Relative } \\
\text { dominance } \\
(\%)\end{array}$ & $\begin{array}{c}\text { Importance } \\
\text { value }(\%)\end{array}$ \\
\hline \multirow{11}{*}{ Natural forest } & Rhizophora apiculata Bl. & Rhizophoraceae & 31.03 & 31.03 & 31.03 & 107.72 \\
\hline & Xylocarpus granatum Koen. & Meliaceae & 51.51 & 51.51 & 51.51 & 105.20 \\
\hline & Bruguiera gymnorrhiza (L.) Lamk. & Rhizophoraceae & 6.08 & 6.08 & 6.08 & 23.97 \\
\hline & Scyphiphora hydrophyllacea C.F.Gaertn. & Rubiaceae & 2.47 & 2.47 & 2.47 & 14.62 \\
\hline & Sonneratia alba J.E. Smith & Lythraceae & 3.90 & 3.90 & 3.90 & 12.94 \\
\hline & Rhizophora stylosa Griff. & Rhizophoraceae & 1.23 & 1.23 & 1.23 & 10.42 \\
\hline & Rhizophora mucronata Lam. & Rhizophoraceae & 1.22 & 1.22 & 1.22 & 7.78 \\
\hline & Bruguiera sexangula (Lour.) Poir. & Rhizophoraceae & 0.93 & 0.93 & 0.93 & 6.94 \\
\hline & Bruguiera hainesii C.G.Rogers & Rhizophoraceae & 0.30 & 0.30 & 0.30 & 3.47 \\
\hline & Sonneratia ovata Back. & Lythraceae & 0.55 & 0.55 & 0.55 & 3.47 \\
\hline & Avicennia alba $\mathrm{Bl}$. & Avicenniaceae & 0.77 & 0.77 & 0.77 & 3.47 \\
\hline \multirow{7}{*}{$\begin{array}{l}\text { Rehabilitated } \\
\text { forest }\end{array}$} & Avicennia alba $\mathrm{B} 1$. & Acanthaceae & 27.96 & 27.96 & 27.96 & 81.55 \\
\hline & Rhizophora apiculata $\mathrm{Bl}$. & Rhizophoraceae & 25.06 & 25.06 & 25.06 & 75.47 \\
\hline & Sonneratia alba J.E. Smith & Lythraceae & 28.40 & 28.40 & 28.40 & 70.59 \\
\hline & Bruguiera gymnorrhiza (L.) Lamk. & Rhizophoraceae & 5.29 & 5.29 & 5.29 & 29.30 \\
\hline & Sonneratia ovata Back. & Lythraceae & 7.67 & 7.67 & 7.67 & 22.96 \\
\hline & Scyphiphora hydrophyllacea C.F.Gaertn. & Rubiaceae & 4.60 & 4.60 & 4.60 & 12.24 \\
\hline & Avicennia marina (Forssk.) Vierh & Acanthaceae & 1.03 & 1.03 & 1.03 & 7.88 \\
\hline \multirow[t]{6}{*}{ Degraded forest } & Sonneratia alba J.E. Smith & Lythraceae & 37.07 & 37.07 & 37.07 & 103.58 \\
\hline & Avicennia alba $\mathrm{Bl}$. & Acanthaceae & 32.45 & 32.45 & 32.45 & 92.51 \\
\hline & Rhizophora apiculata $\mathrm{Bl}$. & Rhizophoraceae & 21.21 & 21.21 & 21.21 & 70.55 \\
\hline & Scyphiphora hydrophyllacea C.F.Gaertn. & Rubiaceae & 6.71 & 6.71 & 6.71 & 15.82 \\
\hline & Xylocarpus granatum Koen. & Meliaceae & 1.81 & 1.81 & 1.81 & 9.31 \\
\hline & Hibiscus tilliaceus L. & Malvaceae & 0.74 & 0.74 & 0.74 & 8.24 \\
\hline
\end{tabular}


Table 4. Structure and diversity of tree stands in natural, rehabilitated and degraded mangrove forests in Sungai Apit, Siak, Riau Indonesia

\begin{tabular}{|c|c|c|c|c|c|c|c|c|c|}
\hline \multirow{2}{*}{ Parameter } & \multicolumn{3}{|c|}{ Rawa Mekar Jaya } & \multicolumn{3}{|c|}{ Sungai Rawa } & \multicolumn{3}{|c|}{ Mengkapan } \\
\hline & NF & RF & DF & NF & RF & DF & NF & RF & DF \\
\hline otal num & 5 & $\begin{array}{c}6 \\
(+20)\end{array}$ & $\begin{array}{l}5 \\
(0)\end{array}$ & 12 & $\begin{array}{c}9 \\
(-25)\end{array}$ & $\begin{array}{c}4 \\
(-66.67)\end{array}$ & 12 & $\begin{array}{c}7 \\
(-41.67)\end{array}$ & $6(-50)$ \\
\hline $\begin{array}{l}\text { Tree density (individuals } \\
\text { per ha) }\end{array}$ & $1755.38^{b}$ & $\begin{array}{c}1233.21^{\mathrm{ab}} \\
(-29.74)\end{array}$ & $\begin{array}{c}1155.44^{\mathrm{ab}} \\
(-34.18)\end{array}$ & $1766.49^{\mathrm{b}}$ & $\begin{array}{c}1344.31^{\mathrm{ab}} \\
(-23.90)\end{array}$ & $\begin{array}{l}866,58^{a} \\
(-50.94)\end{array}$ & $2644.18^{c}$ & $\begin{array}{c}1399.86^{\mathrm{ab}} \\
(-47.06)\end{array}$ & $\begin{array}{l}688.82^{\mathrm{a}} \\
(-74.95)\end{array}$ \\
\hline $\begin{array}{l}\text { Mean diameter }(\mathrm{DBH}, \\
\mathrm{cm})\end{array}$ & $12.37^{\mathrm{a}}$ & $\begin{array}{c}9.4^{\mathrm{a}} \\
(-24.01)\end{array}$ & $\begin{array}{c}8.27^{\mathrm{a}} \\
(-33.14)\end{array}$ & $18.78^{b}$ & $\begin{array}{c}8.15^{\mathrm{a}} \\
(-56.60)\end{array}$ & $\begin{array}{c}10.86^{\mathrm{a}} \\
(-42.17)\end{array}$ & $14.58^{\mathrm{a}}$ & $\begin{array}{c}12.24^{\mathrm{a}} \\
(-16.05)\end{array}$ & $\begin{array}{r}11.75^{\mathrm{a}} \\
(-19.41)\end{array}$ \\
\hline Basal area $\left(\mathrm{m}^{2} / \mathrm{ha}\right)$ & $37.90^{\mathrm{a}}$ & $\begin{array}{c}11.81^{\mathrm{a}} \\
(-68.83)\end{array}$ & $\begin{array}{c}9.70^{\mathrm{a}} \\
(-74.41)\end{array}$ & $55.19^{c}$ & $\begin{array}{c}8.49^{\mathrm{a}} \\
(-84.62)\end{array}$ & $\begin{array}{c}9.45^{\mathrm{a}} \\
(-82.88)\end{array}$ & $48,12^{\mathrm{bc}}$ & $\begin{array}{c}16.70^{\mathrm{a}} \\
(-65.46)\end{array}$ & $\begin{array}{r}11.21^{\mathrm{a}} \\
(-76.70)\end{array}$ \\
\hline $\begin{array}{l}\text { Shanr } \\
\text { Diver }\end{array}$ & 0.70 & $\begin{array}{c}1.16 \\
(64.83)\end{array}$ & $\begin{array}{c}0.72 \\
(2.86)\end{array}$ & 1.34 & $\begin{array}{c}1.42 \\
(5.43)\end{array}$ & $\begin{array}{c}1.10 \\
(-18.05)\end{array}$ & 1.34 & $\begin{array}{c}1.59 \\
(18.64)\end{array}$ & $\begin{array}{c}0.87 \\
(-35.03)\end{array}$ \\
\hline $\begin{array}{l}\text { Pielou's Index of } \\
\text { Evenness }(\mathrm{J})\end{array}$ & 0.44 & $\begin{array}{c}0.90 \\
(106.70)\end{array}$ & $\begin{array}{c}0.66 \\
(50.69)\end{array}$ & 0.56 & $\begin{array}{c}0.68 \\
(21.57)\end{array}$ & $\begin{array}{c}0.79 \\
(41.74)\end{array}$ & 0.56 & $\begin{array}{c}0.82 \\
(46.20)\end{array}$ & $\begin{array}{c}0.49 \\
(-13.06)\end{array}$ \\
\hline $\begin{array}{l}\text { Species Index of } \\
\text { Dominance }(C)\end{array}$ & 0.67 & $\begin{array}{c}0.40 \\
(-39.97)\end{array}$ & $\begin{array}{c}0.55 \\
(-17.84)\end{array}$ & 0.43 & $\begin{array}{c}0.35 \\
(-19.07)\end{array}$ & $\begin{array}{c}0.37 \\
(-13.32)\end{array}$ & 0.35 & $\begin{array}{c}0.24 \\
(-31.71)\end{array}$ & $\begin{array}{c}0.30 \\
(-14.22) \\
\end{array}$ \\
\hline
\end{tabular}

Notes: NF: natural forest; RF: rehabilitated forest; DF: degraded forest. The numbers in brackets for rehabilitated forest and degraded forest showed the percentage of increase (+) or decrease (-) compared to the natural forest.

The results of ANOVA (Analysis of Variance) and DMRT (Duncan's Multiple Range Test) further tests showed a significant difference in tree density in the natural forests, which was higher than that in the rehabilitated and degraded forests. In the natural forest, tree density (individuals per ha) at the three locations was at a high level (more than 1500 trees per hectare). The highest tree density was observed at the natural forest in Mengkapan (2,644.18 individuals per ha), while in Rawa Mekar Jaya and Sungai Rawa had almost at the same level at 1,755.38 and 1,766.49 individuals per ha, respectively. Also, lower tree density occurred in the rehabilitated and degraded forests. Degraded forest showed a decrease in tree density, which was higher than in the rehabilitated zone.

The mean diameter at breast height (DBH) of mangroves tree at the study site was quite large, ranging from 8.27 to $18.78 \mathrm{~cm}$. The highest mean diameter occurred in the natural forest in Sungai Rawa which was significantly different from the others. The mean stem diameter in the natural forest was higher than in the rehabilitated and degraded forests. The stem diameter in the rehabilitated and degraded forests in Rawa Mekar Jaya was almost the same compared to those in Sungai Rawa and Mengkapan, which were higher in the degraded forest. The percentage of decrease in the mean stem diameter in the rehabilitated and degraded forests was not high compared to the natural forest. The lowest and highest decrease in the rehabilitated forest were $16.05 \%$ and $58.26 \% 42.17$ in Mengkapan and Sungai Rawa, respectively.

Basal area is the closure of the mangrove forest zone by tree stems which was determined by the size of stem diameter and tree density. Significant differences in the basal area occur in varying forest conditions in Sungai Rawa in which the natural forest in Sungai Rawa had the highest basal area compared to the other forest conditions in the three villages. Basal area in the natural forests was higher than in the rehabilitated and degraded forests. Also, the degraded forest had lower basal area than that of the rehabilitated. The lowest and highest decreases regarding basal area declined in the rehabilitated forest were 65.46 and $84.62 \%$ in Mengkapan and Sungai Rawa, respectively. The low basal area in the rehabilitated forest of Sungai Rawa was due to the reduced mean stem diameter.

The differences in mean stem diameter and basal area in the rehabilitated forest in Rawa Mekar Jaya, Sungai Rawa and Mengkapan villages were related to plant age after the rehabilitation, stress and percentage of seedling survival. The rehabilitated forest in Mengkapan showed a higher mean stem diameter and basal area due to a longer planting age (seven years). The age of the trees in the rehabilitated forest in Sungai Rawa was longer (5 years), but the mean stem diameter and basal area values were lower than in the rehabilitated forest in Rawa Mekar Jaya. This is due to tidal stress and inundation from seawater which results in a lower survival percentage of mangrove seedlings (40\%) so that during rehabilitation the dead seedlings were replaced with new seedlings with younger age. The percentage of seedling survival of mangrove rehabilitation in Rawa Mekar Jaya is higher (80\%) because the mangrove forest in Rawa Mekar Jaya is directly connected to river.

Tidal stress and seawater inundation reduce the effectiveness of mangrove rehabilitation because it increases seedling mortality and increases costs due to seedling replacement activities. Mangrove rehabilitation is successful if the hydrological environment is suitable for mangrove growth. The survival and growth of mangrove species are related to the depth, duration and frequency of flooding, and soil saturation. Therefore, the most important factor when designing a successful mangrove restoration project is to determine the normal hydrology (depth, duration and frequency, and tidal flooding) of the natural mangrove plants present at the restoration site (Lewis 2005; Lewis 2009). Hydrological restoration has been carried out to rehabilitate an abandoned shrimp pond in Bunaken 
National Park, North Sulawesi, Indonesia in which all the procedures applied were simple and cost-effective, and the results were significantly successful (Djamaluddin et al. 2019).

Diversity and evenness indexes were used to evaluate species diversity and number size, respectively. The Shannon Diversity Index is a widely used method for comparing diversity between different habitats. The diversity index values range from $0-7$ with the following criteria: 0-2 (low), 2-3 (moderate), and > 3 (high) (Setiadi 2005). The diversity index at the nine sampling locations ranged between 0.7 to 1.59 , which was classified as low. The difference in the diversity index from different locations was not too high although there is a tendency in the degraded forest of the Sungai Rawa and Mengkapan to be lower than the natural and rehabilitated forest. However, the diversity at the degraded forest in Rawa Mekar Jaya was the same as at the natural, which was very low (0.7). The low Shannon and Wiener diversity index also occurred in four mangrove forests in the Gulf of Khambhat arid region of Gujarat, west coast of India, which ranged from 0 to 1.179 (Singh 2020).

The evenness index described the size of the number of individuals between species in a community. The more evenly the distribution of individuals between species, the greater the balance of the ecosystem. The index values range from $0-1$ with category: $0<\mathrm{E} \leq 0.4$ (evenly small, stressed communities), $0.4<\mathrm{E} \leq 0.6$ (moderate evenness, unstable communities), and $0.6<\mathrm{E} \leq 1.0$ (high evenness, stable community). The evenness index in the study locations ranged from 0.44 to 0.9 , suggesting that different forest conditions showed balanced values that varied from moderate to high equality. The rehabilitated and degraded forests showed high evenness values ranging from 0.66 to 0.9 , except for the degraded forest in Mengkapan that indicated moderate value $(0.49)$. The natural forest in the three villages had a moderate evenness index with the lowest value was in the village of Rawa Mekar Jaya (0.44). Also, the highest evenness index value was in the rehabilitated forest in Rawa Mekar Jaya. These results indicated that mangrove revegetation activities increased the evenness of species when compared to the natural forest with the highest increase in the village of Rawa Mekar Jaya.

The dominance index indicates the domination or extinction of species in an area. The index values range from 0 to 1 with categories of $0<\mathrm{C}<0.5,0.5<\mathrm{C} \leq 0.75$, and $0.75<\mathrm{C} \leq 1.0$, representing low, moderate, and high dominance, respectively (Ludwig and Reynolds 1988). The dominance index values in the nine research locations ranged from 0.24 to 0.67 , indicating a low to moderate dominance. Moderate dominance only occurred in the natural (0.67) and degraded (0.55) forests in Rawa Mekar Jaya. However, the other seven locations showed low dominance with index from 0.24 to 0.40 . The natural and degraded forests in Rawa Mekar Jaya had higher dominance values because there was still greater domination of species compared to other locations. $R$. apiculata dominated the natural and degraded forests with important values of $210.07 \%$ and $192.79 \%$. Also, the rehabilitated forests showed a decrease in their dominance value. This indicates that mangrove rehabilitation resulted in an increase in species diversity and evenness, but a decreased in species dominance. This is because, during the rehabilitation activities, a large number of mangrove species were planted.

\section{Seedling structure and species composition}

The number of species and seedling density per ha can be seen in Figure 2, while the species composition and importance value are presented in Tables 5, 6, 7.

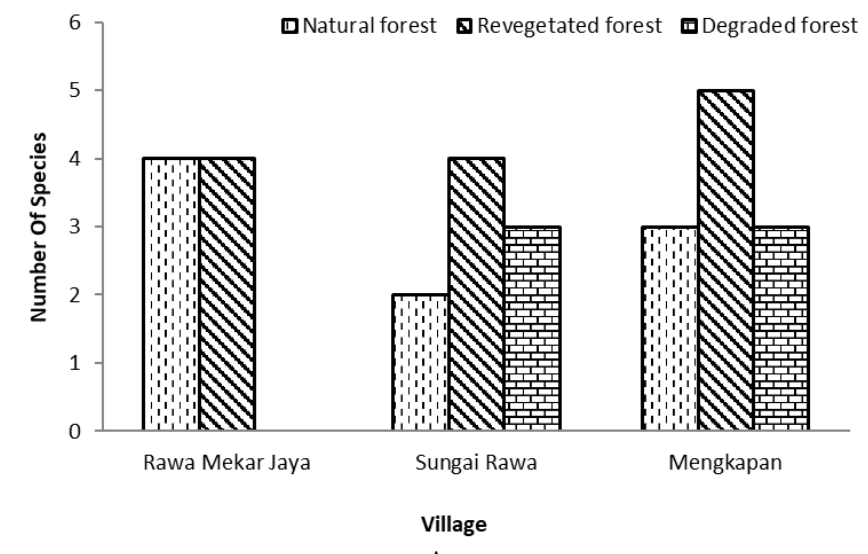

A

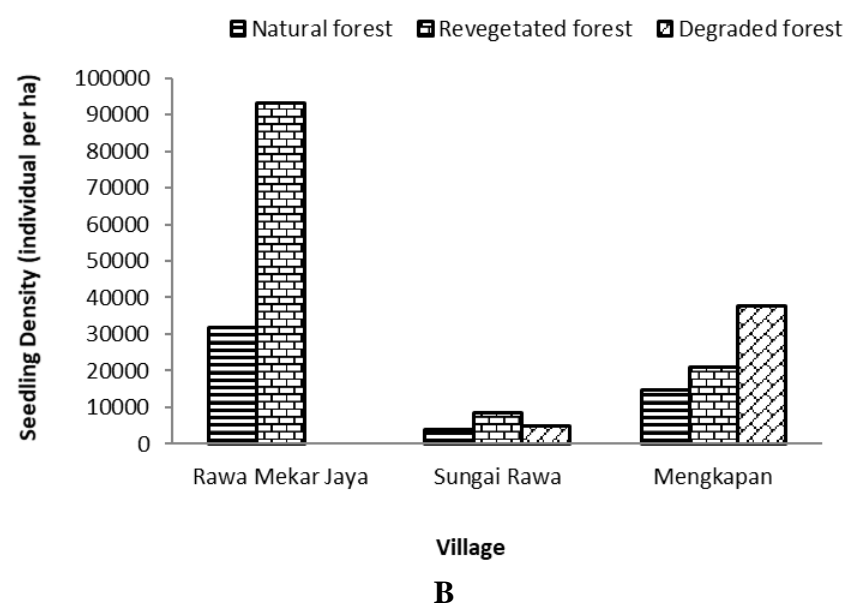

Figure 2. Number of species and density of seedlings in mangrove forest with varying conditions in Sungai Apit, Siak, Indonesia: A. Number of species and B. Seedling density per ha 
Table 5. Species composition and dominance of seedling in Rawa Mekar Jaya, Sungai Apit Siak, Riau, Indonesia

\begin{tabular}{|c|c|c|c|c|c|}
\hline Forest condition & Species & Family & $\begin{array}{c}\text { Relative } \\
\text { density }(\%)\end{array}$ & $\begin{array}{c}\text { Relative } \\
\text { frequency }(\%)\end{array}$ & $\begin{array}{c}\text { Importance } \\
\text { value }(\%)\end{array}$ \\
\hline \multirow[t]{4}{*}{ Natural forest } & Rhizophora apiculata & Rhizophoraceae & 70.43 & 57.14 & 127.58 \\
\hline & Rhizophora mисronata & Rhizophoraceae & 21.74 & 28.57 & 50.31 \\
\hline & Bruguiera sexangula & Rhizophoraceae & 6.09 & 7.14 & 13.23 \\
\hline & Acrostichum aureum & Pteridaceae & 1.74 & 7.14 & 8.88 \\
\hline \multirow[t]{4}{*}{ Rehabilitated forest } & Rhizophora apiculata & Rhizophoraceae & 86.36 & 50 & 136.36 \\
\hline & Bruguiera sexangula & Rhizophoraceae & 10.45 & 30 & 40.45 \\
\hline & Rhizophora mucronata & Rhizophoraceae & 2.73 & 10 & 12.73 \\
\hline & Santiria laevigata Blume & Burseraceae & 0.45 & 10 & 10.45 \\
\hline
\end{tabular}

Degraded forest

Table 6. Species composition and dominance of seedling in Sungai Rawa, Sungai Apit, Siak, Riau, Indonesia

\begin{tabular}{lllccc}
\hline Forest condition & \multicolumn{1}{c}{ Species } & \multicolumn{1}{c}{ Family } & $\begin{array}{c}\text { Relative } \\
\text { density }(\boldsymbol{\%})\end{array}$ & $\begin{array}{c}\text { Relative } \\
\text { frequency }(\boldsymbol{\%})\end{array}$ & $\begin{array}{c}\text { Importance } \\
\text { value }(\boldsymbol{\%})\end{array}$ \\
\hline Natural forest & $\begin{array}{l}\text { Rhizophora apiculata } \\
\text { Bruguiera parviflora }\end{array}$ & Rhizophoraceae & 92.86 & 66.67 & 159.52 \\
& & Rhizophoraceae & 7.14 & 33.33 & 40.48 \\
Rehabilitated forest & Rhizophora apiculata & Rhizophoraceae & 32.26 & 57.14 & 89.40 \\
& Sonneratia alba & Lythraceae & 48.39 & 14.29 & 62.67 \\
& Ceriops tagal & Rhizophoraceae & 9.68 & 14.29 & 23.96 \\
& Xylocarpus granatum & Meliaceae & 9.68 & 14.29 & 23.96 \\
Degraded forest & & & 52.94 & 50 & 102.94 \\
& Avicennia alba & Acanthaceae & 45.10 & 33.33 & 78.43 \\
& Sonneratia alba & Lythraceae & 1.96 & 16.67 & 18.63 \\
\hline
\end{tabular}

Table 7. Species composition and dominance of seedling in Mengkapan, Sungai Apit, Siak, Riau, Indonesia

\begin{tabular}{|c|c|c|c|c|c|}
\hline Forest condition & Species & Family & $\begin{array}{c}\text { Relative density } \\
(\%)\end{array}$ & $\begin{array}{c}\text { Relative } \\
\text { frequency }(\%)\end{array}$ & $\begin{array}{c}\text { Importance } \\
\text { value }(\%)\end{array}$ \\
\hline \multirow[t]{4}{*}{ Natural forest } & Rhizophora apiculata & Rhizophoraceae & 37.74 & 50.00 & 87.74 \\
\hline & Bruguiera gymnorrhiza & Rhizophoraceae & 52.83 & 33.33 & 86.16 \\
\hline & Scyphiphora hydrophyllacea & Rubiaceae & 1.89 & 16.67 & 18.55 \\
\hline & Sonneratia alba & Lythraceae & 7.55 & 0.00 & 7.55 \\
\hline \multirow[t]{5}{*}{ Rehabilitated forest } & Avicennia alba & Acanthaceae & 79.37 & 37.50 & 116.87 \\
\hline & Rhizophora apiculata & Rhizophoraceae & 12.70 & 25.00 & 37.70 \\
\hline & Sonneratia ovata & Lythraceae & 3.17 & 12.50 & 15.67 \\
\hline & Sonneratia alba & Lythraceae & 3.17 & 12.50 & 15.67 \\
\hline & Bruguiera gymnorrhiza & Rhizophoraceae & 1.59 & 12.50 & 14.09 \\
\hline \multirow[t]{5}{*}{ Degraded forest } & Avicennia alba & Acanthaceae & 79.37 & 37.50 & 116.87 \\
\hline & Rhizophora apiculata & Rhizophoraceae & 12.70 & 25.00 & 37.70 \\
\hline & Sonneratia ovata & Lythraceae & 3.17 & 12.50 & 15.67 \\
\hline & Sonneratia alba & Lythraceae & 3.17 & 12.50 & 15.67 \\
\hline & Bruguiera gymnorrhiza & Rhizophoraceae & 1.59 & 12.50 & 14.09 \\
\hline
\end{tabular}

The number of seedling species was observed to be lower ( 0 to 5 species) compared to that of tree (4 to 12 species). The lowest and highest numbers of species were recorded in the degraded and rehabilitated forests, respectively. The seedling density also ranged from 0 to 93055 individuals/ha. The highest and lowest seedling densities (individuals per ha) were also observed to be in the rehabilitated and degraded forests in Rawa Mekar Jaya as they did not grow seedlings. Generally, the three locations indicated that natural forests showed the lowest abundance of seedlings compared to rehabilitated and degraded forests. The abundance of seedlings in the degraded forest in Sungai Rawa and Mengkapan was higher than that of the rehabilitated. Seedling colonization is related to differences in mangrove canopy as higher shade inhibits seed germination. The degraded forest in Rawa Mekar Jaya did not grow seedlings due to the high level of canopy as it was close to land clearing for oil palm 
plantations. The creation of canals the degraded forests for oil palm plantation in inhibited seedling colonization. The fallen mangrove seeds did not grow, possibly due to high canopy levels and physical stress. Also, the rehabilitated forest had a higher ability to regenerate due to the lower level of cover which promotes germination and growth of mangrove seeds. Additionally, the higher density of the trees in the rehabilitated forest allowed mangrove plants to produce more seeds than in the degraded zones. The existence of canopy gaps also stimulated seed germination and growth of mangrove seedlings. This was supported by the research results of Azad et al. (2020) which showed that the density of mangrove seedlings in the gap was higher than in the canopy. High seedling density was an indication of mangrove forest regeneration, suggesting to ecosystem recovery. Strong regeneration of forests was also demonstrated in mangrove ecosystems in Mwache, Kenya (Alemayehu and Wekesa 2017).

The species composition and dominance of seedlings are shown in Tables 5, 6, and 7. The dominant species at seedling level in varying conditions of mangrove forest were almost the same as tree species. The dominant seedling species in the natural and rehabilitated forest was $R$. apiculata with a dominance level of around $89.40 \%$ to $159.52 \%$, except for the rehabilitated forest in Mengkapan which was dominated by A. alba (116.87\%). Also, in Rawa Mekar Jaya, seedlings did not grow in the degraded forest as $A$. alba dominated in the degraded mangrove of Sungai Rawa and Mengkapan.

The species of seedling that dominated mangrove forests in different conditions showed the ability to regenerate naturally than other species. The species that dominated the degraded forest in Sungai Rawa, included $A$. alba (102.94\%), S. alba (78.43\%) and in Mengkapan included A. alba (116.87\%), R. apiculata (37.70\%). However, for mangrove rehabilitation, other species of seedlings should be used as alternatives, including $R$. mucronata, B. sexangula, Bruguiera parviflora, Ceriops tagal, X. granatum, Sonneratia ovata, and Bruguiera gymnorrhiza. Several mangrove species had the potential to regenerate naturally, including $A$. alba, S. alba, and $R$. apiculata in Payum, Merauke, Papua Province (Wairara and Sianturi 2019); B. gymnorrhiza, R. mucronata, S. alba and $R$. stylosa in Pannikiang Island, South Sulawesi (Paembonan et al. 2020); Ceriops tagal in the Kemujan Island, Karimunjawa National Park, Indonesia (Winata et al. 2017).

The characteristics of stands that affected mangrove seedling abundance were tree density and basal area. The results of this study indicated a trend that the higher the tree density and basal area, the lower the abundance of seedlings. The natural forest had a higher tree density and basal area than in the rehabilitated and degraded forests. However, the rehabilitated forest had a higher tree density than the degraded mangroves. The abundance of mangrove seedlings in the degraded forest was observed to be higher than the natural and rehabilitated forest in Mengkapan. Degraded forest in Rawa Mekar Jaya did not grow seedlings although the abundance of young plants showed the same trend. This indicated that the abundance of seedlings in the rehabilitated forest was higher than in the natural mangroves. Lower mangrove tree density further indicated a higher abundance of seedlings associated with the number of gaps. According to Azad et al. (2020), gaps in mangrove forests increased the colonization of seedlings. The formation of gaps in the mangrove forest canopy can create regeneration. Seeds that were dormant under the canopy had a chance to grow in place of dead trees (Amir 2012). An increase in light and temperature in forest gaps are important in seed colonization due to their importance in breaking dormancy and seedling growth. Based on the results of this study, the degraded mangrove forests experienced good natural regeneration when there was no physical pressure or continuous degradation.

In many areas in the world, degraded mangrove forests are able to regenerate naturally. Comparison between natural mangrove regeneration and human-assisted regeneration after Hurricane Mitch in the Gulf of Honduras, Guanaja did not show a significant difference in the success of mangrove replanting (Fickert 2020). A total of 23 species of mangrove were recorded and they had good ability in terms of natural regeneration in several mangrove forests affected by the tsunami, including in the North Coast of Aceh, the East coast of Aceh, the West coast of Aceh and the coast of Peninsular Malaysia (Onrizal et al. 2017). Natural regeneration in forest areas without restoration was higher than mangrove forests that were not restored in Jaguaribe River mangrove forests, Rio Grande do Norte, Brazil after 5 years (Ferreira et al. 2015). Mangrove forests in $\mathrm{Ca}$ Mau Province, Vietnam which were degraded after 35 years showed the same vegetation structure, both restored and regenerating naturally (Nam et al. 2016).

In the degraded mangroves of Sungai Apit, Siak, Indonesia, natural regeneration and high levels of resuscitation in different forest conditions were an important part of mangrove rehabilitation. The natural regeneration of mangrove vegetation contributed to the maintenance of existing communities. Mangrove vegetation also had progressive, dynamic, and successful regenerative processes. This showed that the existence of this natural regeneration strategy was able to overcome the adverse situation in the habitat. This natural regeneration further allowed the damaged condition of the mangrove forest to change for good. This was due to the fact that growing seedlings were to become trees, which in turn leads to an increase in tree densities. Therefore, natural regeneration of mangrove vegetation is important for the preservation of the ecosystem.

In conclusion, 20 species from 11 families were recorded in mangrove forests with varying conditions in Sungai Apit, Siak, Riau. The highest and lowest number of species were observed in the natural and degraded forests, respectively. The most dominant species was $R$. apiculata, which dominated across all forest conditions. Differences in tree density, the mean diameter of mangrove stems, and basal areas that occurred in the three forest conditions with the natural forest showed the highest value. There was a decrease in tree density, the mean diameter of mangrove stems, and basal areas in the rehabilitated and degraded 
forests when compared to natural forests. Tree density, the mean diameter of mangrove stems, and basal areas in the rehabilitated forests were higher than in the degraded forests, but the mean diameter of mangrove stems and basal areas in the rehabilitated forests in Sungai Rawa was lower. This is because of the younger planting age, stress, and replacement of new seedlings due to the lower success rate of growing seedlings. The lowest and highest number of seedling species were observed in the degraded and rehabilitated forests. The number of seedling species was also lower than species values in tree stands. Seedling density in the natural forest was lower than rehabilitated and degraded forests.

\section{ACKNOWLEDGEMENTS}

We are grateful for the acceptance, support, and provision of facilities from local communities in Sungai Apit, Siak, Riau, Indonesia, and assistance from field technicians during the field sampling.

\section{REFERENCES}

Alemayehu F, Wekesa C. 2017. Structure and natural regeneration of mangroves in areas exposed to different agents of degradation in Kenya. J Global Biosci 6 (61): 4695-4707.

Amir AA. 2012. Canopy gaps and the natural regeneration of Matang mangroves. For Ecol Manag 269: 60-67. DOI: 10.1016/j.foreco.2011.12.040.

Azad MS, Kamruzzaman M, Kanzaki M. 2020. Canopy gaps influence regeneration dynamics in cyclone-affected mangrove stands in medium saline zone of the Sundarbans, Bangladesh. Acta Ecol Sin 41 (4): 296-303. DOI: 10.1016/j.chnaes.2020.03.002.

Budiharta S. 2010. Floristic composition at biodiversity protection area in Lubuk Kakap, District of Ketapang, West Kalimantan. Biodiversitas 11: 151-156. DOI: 10.13057/biodiv/d110309.

Brander LM, Wagtendonk AJ, Hussain SS, McVittie A, Verburg PH, de Groot RS, van der Ploeg S. 2012. Ecosystem service values for mangroves in Southeast Asia: A meta-analysis and value transfer application. Ecosyst Serv 1 (1): 62-69. DOI: 10.1016/j.ecoser.2012.06.003.

Campbell A, Brown B. 2015. Indonesia's vast mangroves are a treasure worth saving. The Conversation. http://theconversation.com/indonesias-vast-mangroves-are-a-treasureworth-saving-39367

Dharmawan IWE, Widyastuti A. 2017. Pristine mangrove community in Wondama Gulf, West Papua, Indonesia. Mar Res Indon 42 (2): 73-82. DOI: $10.14203 / \mathrm{mri} . v 42 \mathrm{i} 2.175$.

Djamaluddin R, Brown B, Lewis RR. 2019. The practice of hydrological restoration to rehabilitate abandoned shrimp ponds in Bunaken National Park, North Sulawesi, Indonesia. Biodiversitas 20 (1): 160170. DOI: 10.13057/biodiv/d200119.

Efriyeldi, Mulyadi A, Samiaji J, Siregar SH, Elizal, Ramadhan AR, Rizki A, Yanti DH, Despela, Sari DJ, Rahmita R, Ginting TB, Wahyudi, Desmarina Y, Zientika. 2020. Improvement of knowledge and skills of the laskar mandiri conservation group in seeding and planting mangrove in the Village of Kayu Ara Permai, Siak Regency. J Rural Urban Commun Empowerm 2 (1): 15-23. [Indonesian]

FAO. 2007. The World's Mangroves 1980-2005. Food and Agriculture Organization of the United Nations, Rome, IT.

Ferreira AC, Ganade G, de Attayde JL. 2015. Restoration versus natural regeneration in a neotropical mangrove: Effects on plant biomass and crab communities. Ocean Coast Manag 110: 38-45. DOI 10.1016/j.ocecoaman.2015.03.006.

Fickert T. 2020. To plant or not to plant, that is the question: reforestation vs. natural regeneration of hurricane-disturbed mangrove forests in Guanaja (Honduras). Forests 11 (10): 1068. DOI: 10.3390/f11101068.
Giri C, Ochieng E, Tieszen LL, Zhu Z, Singh A, Loveland T, Masek J, Duke N. 2011. Status and distribution of mangrove forests of the world using earth observation satellite data. Global Ecol Biogeogr 20 (1): 154-159. DOI: $10.1111 /$ j.1466-8238.2010.00584.x.

Lewis RR. 2005. Ecological engineering for successful management and restoration of mangrove forests. Ecol Eng 24 (4) 403-418. DOI: /10.1016/j.ecoleng.2004.10.003.

Lewis RRL. 2009. Chapter 28 - Methods and Criteria for Successful Mangrove Forest Restoration. In: Coastal Wetlands: An Integrated Ecosystem Approach. Elsevier, Nederlands. DOI: 10.1016/B978-0444-53103-2.00028-4.

Kantharajan G, Pandey PK, Krishnan P, Ragavan P, Jeevamani JJJ, Purvaja R, Ramesh R. 2018. Vegetative structure and species composition of mangroves along the Mumbai coast, Maharashtra, India. Reg Stud Mar Sci 19, 1-8. DOI: 10.1016/j.rsma.2018.02.011.

Mauludin MR, Ria A, Rudhi PS. 2018. Komposisi dan tutupan kanopi mangrove di kawasan Ujung Piring Kabupaten Jepara. Buletin Oseanografi Marina 7 (1): 29-36. [Indonesian]

Mukhlisi M, Nuryani A, Sayektiningsih T. 2020. Monitoring of floristic composition and species diversity an initial step towards the restoration of mangrove forest in Teluk Adang nature reserve, Indonesia. Polish J Environ Stud 30 (1): 793-802. DOI: 10.15244/pjoes/123608.

Mulyadi A, Amin B. 2016. Vegetation structure and mangrove ecosystem threats in the coastal zone of Dumai, Riau, Indonesia. Intl J Appl Environ Sci 11 (3): 785-798.

Nam VN, Sasmito SD, Murdiyarso D, Purbopuspito J, MacKenzie RA. 2016. Carbon stocks in artificially and naturally regenerated mangrove ecosystems in the Mekong Delta. Wetlands Ecol Manag 24 (2): 231-244. DOI: 10.1007/s11273-015-9479-2.

Njana MA. 2020. Structure, growth, and sustainability of mangrove forests of mainland Tanzania. Global Ecol Conserv 24: e01394. DOI: 10.1016/j.gecco.2020.e01394.

Onrizal O. 2008. Ecological study on mangrove forest in East Coast of North Sumatra. Biodiversitas 9 (1): 25-29. DOI: 10.13057/biodiv/d090107.

Onrizal, Ahmad AG, Mansor M. 2017. Assessment of Natural Regeneration of Mangrove Species at Tsunami Affected Areas in Indonesia and Malaysia. IOP Conf Ser Mater Sci Eng 180 (1): 012045. DOI: 10.1088/1757-899X/180/1/012045.

Owuor MA, Mulwa R, Otieno P, Icely J, Newton A. 2019. Valuing mangrove biodiversity and ecosystem services: A deliberative choice experiment in Mida Creek, Kenya. Ecosyst Services 40: 101040. DOI: 10.1016/j.ecoser.2019.101040.

Paembonan SA, Bachtiar B, Ridwan M. 2020. Sustainable forest management through natural mangrove regeneration on Pannikiang Island, South Sulawesi. IOP Conf Ser: Earth Environ Sci 486(1): p012082. DOI: 10.1088/1755-1315/486/1/012082.

Pielou EC. 1969. An Introduction to Mathematical Ecology. Wiley, New York.

Pototan BL, Capin NC, Delima AGD, Novero AU. 2021. Assessment of mangrove species diversity in Banaybanay, Davao Oriental, Philippines. Biodiversitas 22 (1): 144-153. DOI: $10.13057 /$ biodiv/d220120.

Rasquinha DN, Mishra DR. 2020. Impact of wood harvesting on mangrove forest structure, composition and biomass dynamics in India. Estuar Coast Shelf Sci 248: 106974. DOI: 10.1016/j.ecss.2020.106974

Sawale AK, Thivakaran G. 2013. Structural characteristics of mangrove forest of Kachchh, Gujarat. J Mar Biol Assoc India 55 (1): 5-11. DOI: 10.6024/jmbai.2013.55.1.01735-01.

Setiadi D. 2005. The diversity of trees species in Taman Wisata Alam Ruteng, East Nusa Tenggara. Biodiversitas 6 (2): 118-122. DOI: 10.13057/biodiv/d060210.

Shah K, Mustafa KAH, Rosli Z, Hakeem KR, Hoque MM. 2016. Composition and diversity of plants in Sibuti mangrove forest, Sarawak, Malaysia. For Sci Technol 12 (2): 70-76. DOI: 10.1080/21580103.2015.1057619.

Singh JK. 2020. Structural characteristics of mangrove forest in different coastal habitats of Gulf of Khambhat arid region of Gujarat, west coast of India. Heliyon 6 (8), e04685. DOI: 10.1016/j.heliyon.2020.e04685.

Sreelekshmi S, Nandan SB, Kaimal SV, Radhakrishnan CK, Suresh VR. 2020. Mangrove species diversity, stand structure and zonation pattern in relation to environmental factors - A case study at 
Sundarban delta, east coast of India. Reg Stud Mar Sci 35, 101111. DOI: 10.1016/j.rsma.2020.101111.

Vo QT, Kuenzer C, Vo QM, Moder F, Oppelt N. 2012. Review of valuation methods for mangrove ecosystem services. Ecol Indic 23, 431-446. DOI: 10.1016/j.ecolind.2012.04.022.

Winata A, Yuliana E, Rusdiyanto E. 2017. Diversity and natural regeneration of mangrove vegetation in the tracking area on Kemujan
Island Karimunjawa National Park, Indonesia. Advan Environ Sci 9 (2): 109-119.

Wairara SMBS, Sianturi R. 2019. Potential regeneration of mangrove coastal of Payum beach Merauke District. Musamus Fish Mar J 2 (1): 11-22. DOI: $10.35724 / \mathrm{mfmj} . v 2 \mathrm{i} 1.1869$. [Indonesian]

Yurizal. 2018. Analisis ekonomi rumah tangga nelayan di sekitar kawasan hutan mangrove Desa Kuala Selat Kecamatan Kateman Kabupaten Indragiri Hilir. JOM FEB 1 (1). [Indonesian] 